\title{
ESC-3 induces apoptosis of human ovarian carcinomas through Wnt// -catenin and Notch signaling in vitro and in vivo
}

\author{
QI-RUI FU ${ }^{1 *}$, WEI SONG ${ }^{2 *}$, YI-TAO DENG ${ }^{1}$, HUA-LIANG LI ${ }^{1}$, XIAO-MEI MAO ${ }^{1}$, CHEN-LU LIN ${ }^{1}$, \\ YA-HUI ZHENG ${ }^{1}$, SHU-MING CHEN ${ }^{1}$, QIONG-HUA CHEN ${ }^{3}$ and QING-XI CHEN ${ }^{1}$ \\ ${ }^{1}$ State Key Laboratory of Cellular Stress Biology, Key Laboratory of the Ministry of Education \\ for Coastal and Wetland Ecosystems, School of Life Sciences, Xiamen University, Xiamen, Fujian 361005; \\ ${ }^{2}$ College of Life Science and Engineering, Henan University of Urban Construction, Ping Dingshan, Henan 467036; \\ ${ }^{3}$ Department of Obstetrics and Gynecology, The First Affiliated Hospital of Xiamen University, \\ Xiamen, Fujian 361003, P.R. China
}

Received July 6, 2016; Accepted November 7, 2016

DOI: $10.3892 /$ ijo.2016.3773

\begin{abstract}
Apoptosis, programmed cell death under physiological or pathological conditions, plays a critical role in the tissue homeostasis of eukaryotes. It is desirable to prevent the occurrence and metastasis of cancer through inducing apoptosis. Our previous study demonstrated that apoptosis could be induced by extract from crocodile in human cholangiocarcinoma. ESC-3, a novel cytotoxic compound isolated from the extract induced apoptosis in Mz-ChA-1 cells via the mitochondria-dependent pathway in a dose-dependent manner. In this study, ESC-3 significantly inhibited the proliferation of A2780 cells and arrested the cells at $\mathrm{G}_{2} / \mathrm{M}$ phase. After exposure to ESC-3, A2780 cells displayed typical morphological changes and the ability of colony-forming was remarkably inhibited. ESC-3 could significantly upregulate the expression of Bax proteins while $\mathrm{Bcl}-2$ protein remained unchanged, resulting in the elevation of $\mathrm{Bax} / \mathrm{Bcl}-2$ ratio, which usually could induce
\end{abstract}

Correspondence to: Dr Qing-Xi Chen, State Key Laboratory of Cellular Stress Biology, Key Laboratory of the Ministry of Education for Coastal and Wetland Ecosystems, School of Life Sciences, Xiamen University, Xiamen, Fujian 361005, P.R. China

E-mail: chenqx@xmu.edu.cn

Dr Qiong-Hua Chen, Department of Obstetrics and Gynecology, The First Affiliated Hospital of Xiamen University, Xiamen, Fujian 361003, P.R. China

E-mail: cqhua616@126.com

*Co-first authors

Abbreviations: $\mathrm{SCB}$, siamese crocodile bile; $\mathrm{OvCa}$, ovarian cancer; FBS, fetal bovine serum; DMEM, Dulbecco's modified Eagle's essential medium; CCK-8, cell counting kit-8; DMSO, dimethyl sulfoxide; FITC, fluorescein isothiocyanate; PI, propidium iodide; PVDF, polyvinylidene difluoride; PMSF, phenylmethanesulfonyl fluoride; VEGF, vascular endothelial growth factor

Key words: ESC-3, apoptosis, ovarian carcinomas, xenograft models, Notch signaling apoptosis. The critical protein of Wnt signaling ( $\beta$-catenin) was significantly downregulated, whereas Hes1, the downstream protein of Notch signaling, was remarkably attenuated through upregulating the expression of P53. In addition, xenograft models demonstrated that ESC-3 effectively suppressed the growth of OvCa tumors $(\mathrm{T} / \mathrm{C}=42 \%)$. Western blot analysis of PCNA and VEGF confirmed that ESC-3 could inhibit the growth and metastasis of OvCa tumors. In conclusion, apoptosis could be induced by ESC-3 through Wnt/ $\beta$-catenin and Notch signaling in vitro and in vivo, and might have therapeutic potential for the treatment of human OvCa.

\section{Introduction}

In all gynecologic cancers, ovarian cancer $(\mathrm{OvCa})$ is one of the most lethal, mostly diagnosed at advanced stages for lack of the effective prior-diagnostic methods (1). It ranked the fifth most common cause of cancer-related death among women in the United States (2). After tumor cytoreductive surgery or administration of platinum-based chemotherapy, almost all the patients developed recurrent and disseminated malignancies with multiple drug resistance $(3,4)$. Approximately $30 \%$ of epithelial ovarian cancer patients died in less than five years even with the progress in therapeutic methods (5). Therefore, it is urgent and essential to develop a novel non-toxic drug for improving the existing therapy.

Bile is composed by large amounts of bile acids such as chenodeoxycholic acid (CDCA), ursodeoxycholic acid (UDCA), cholic acid (CA), and deoxycholic acid (DCA) (6). Snake bile has been found to possess anti-inflammatory, anti-convulsion and analgesic physiological functions (7). In a previous study, we found that extracts from Crocodylus siamensis bile could induce apoptosis effectively in human cholangiocarcinoma cells lines (QBC939, Sk-ChA-1 and MZ-ChA-1) and liver cancer cell (SMMC-7721) (8). After purifying from the extracts, we obtained a more effective inducer ESC-3 (9) and studied the localization of prohibitin during apoptosis of human cholangiocarcinoma Mz-ChA-1 cells (10). However, it is still unclear whether ESC-3 could suppress the growth of ovarian tumor and the xenograft tumorigenesis in vivo. 
In this study, we firstly demonstrated the antitumor effects of novel inducer ESC-3 on human ovarian carcinomas cell lines (A2780 cells, SKOV-3 cells and OVCAR-3 cells) in vitro and elucidated its inducing apoptosis mechanism. We also employed A2780 xenograft models to confirm the effectiveness and the potential as a candidate for ovarian cancer therapy.

\section{Materials and methods}

Cell preparation. SKOV-3 and IOSE-80 cells were cultured in Roswell Park Memorial Institute (RPMI)-1640 medium supplemented with $10 \%$ FBS and penicillin $(100 \mathrm{U} / \mathrm{ml}) / \mathrm{strep}$ tomycin $(100 \mu \mathrm{g} / \mathrm{ml})$. The human OvCa A2780 cells were cultured in DMEM, supplemented with $10 \% \mathrm{FBS}$, penicillin (100 U/ml) and streptomycin $(100 \mu \mathrm{g} / \mathrm{ml})$. OVCAR-3 cells were cultured in complete medium supplemented with $10 \mu \mathrm{g} / \mathrm{ml}$ insulin. Cells were incubated at $37^{\circ} \mathrm{C}$ in a humidified atmosphere of $95 \%$ air and $5 \% \mathrm{CO}_{2}$.

Cell proliferation assay. Cell viability was determined using the CCK-8 assay. A2780 cells were treated with ESC-3 at different concentrations $(0,5,10,20,40$ and $80 \mu \mathrm{g} / \mathrm{ml})$ for 24, 48 and $72 \mathrm{~h}$, respectively. Cell viability was determined using CCK-8 according to the manufacturer's instructions. Briefly, $4 \times 10^{3}$ cells per well were seeded in a 96-well plate and incubated at $37^{\circ} \mathrm{C}$ for $24 \mathrm{~h}$. Subsequently, cells were treated with different concentrations of ESC-3 for 24, 48 and $72 \mathrm{~h}$ respectively. Then $10 \mu \mathrm{l}$ WST- 8 dye was added to each well, cells were incubated at $37^{\circ} \mathrm{C}$ for $1 \mathrm{~h}$ and the absorbance was finally determined at $450 \mathrm{~nm}$ using a microplate reader.

Morphological changes. The cells from control group and the group treated with ESC-3 $(40 \mu \mathrm{g} / \mathrm{ml})$ for $48 \mathrm{~h}$ were seeded onto coverslips and grown for $24 \mathrm{~h}$. After washing with PBS three times, the cells were stained with Giemsa staining solution/Hoechst 33258/AO\&EB and observed under standard inverted phase-contrast microscope or a fluorescence microscope.

Colony-forming assay. Cells were plated into a 6-well culture plate (1,200 cells/well) and allowed to adhere for $12 \mathrm{~h}$ before treatment. The next day, cells were treated with ESC-3 and equal volumes of DMSO. After $48 \mathrm{~h}$, ESC-3-containing media was removed, and cells were allowed to form colonies in serum-free media for 14 days, and then the colonies were fixed with a solution of acetic acid and methanol (1:3) for $15 \mathrm{~min}$, stained with Giemsa for 15 min and counted manually.

Flow cytometry assay. Cells were treated with ESC-3 (5, 10 , 20,40 and $80 \mu \mathrm{g} / \mathrm{ml}$ ) for $48 \mathrm{~h}$ and then collected and washed twice with PBS. After fixing in ice-cold $70 \%$ ethanol for $12 \mathrm{~h}$, the samples were washed twice with PBS and then incubated with $10 \mathrm{mg} / \mathrm{ml} \mathrm{RNase}$ and $1 \mathrm{mg} / \mathrm{ml}$ PI (propidium iodide) for $30 \mathrm{~min}$ in the dark. Finally, the samples were evaluated by Flow Cytometry 500, and the data were analyzed using Cell Fit software. The Annexin V-fluorescein isothiocyanate (V-FITC)/PI double staining assay was conducted to quantify cell apoptotic proportion according to the manufacturer's instructions. Briefly, after exposure to $40 \mu \mathrm{g} / \mathrm{ml} \mathrm{ESC}-3$ the
A2780 cells were harvested and stained with Annexin V-FITC and PI for $20 \mathrm{~min}$ at room temperature. Following washing with PBS, we used Flow Cytometry 500 to detect the fluorescence of the cells.

Western blot analysis. To explore the mechanism of apoptosis induced by ESC-3, proteins were extracted with RIPA buffer (10 mM Tris, $150 \mathrm{mM} \mathrm{NaCl,} 0.5 \%$ NP-40, 0.1\% SDS, $0.1 \%$ deoxycholate, $1 \mathrm{mM}$ PMSF, $2 \mathrm{mM}$ sodium fluoride, and $1 \mathrm{mM}$ sodium orthovanadate), then centrifuged at 13,000 rpm for $30 \mathrm{~min}$ at $4^{\circ} \mathrm{C}$. Briefly, equivalent amounts of proteins were analyzed by $10-15 \%$ SDS-PAGE, then transferred onto polyvinylidene difluoride (PVDF) membranes (Millipore, Bedford, MA, USA), which were then incubated with specific primary antibodies. Finally, proteins were visualized with peroxidasecoupled secondary antibody, using the ECL system (Pierce Co., USA) for detection.

Xenograft models. Female Balb/c nude mice (16 $\pm 2 \mathrm{~g})$ were purchased from SLRC Laboratory Animal Co.,Ltd. Shanghai, China. The animals were kept on 12-h-light/12-h-dark cycle under the condition of a constant temperature of $21-22^{\circ} \mathrm{C}$ and $60-65 \%$ humidity. Additionally, they were maintained on standard pellet diet and water ad libitum throughout the experiments. The experimental procedures were performed in accordance with the guidelines for the humane treatment of animals set by the Laboratory Animal Center. Briefly, $\sim 5 \times 10^{6}$ A2780 cells were subcutaneously injected into nude mice to establish human ovarian cancer xenograft. When the tumor reached a volume of $100 \mathrm{~mm}^{3}$, the mice were randomized to control and treatment groups, then the control groups received corn oil (every three days, i.g. administration) and the other groups $50 \mathrm{mg} / \mathrm{kg} \mathrm{ESC}-3$ (every other three days, i.g. administration) for 30 days. Tumor volume (V) was calculated as $\mathrm{V}=\left(\right.$ length $\mathrm{x}$ width $\left.{ }^{2}\right) / 2$. The tumor volume at day $\mathrm{n}$ was expressed as relative tumor volume (RTV) according to the following formula: $\mathrm{RTV}=\mathrm{TV}_{\mathrm{n}} / \mathrm{TV}_{0}$, where $\mathrm{TV}_{\mathrm{n}}$ is the tumor volume at day $n$ and $\mathrm{TV}_{0}$ is the tumor volume at day 0 . Therapeutic effects of treatment were expressed in terms of $\mathrm{T} / \mathrm{C}(\%)$ using the calculation formula $\mathrm{T} / \mathrm{C}(\%)=$ mean RTV of the treated group/mean RTV of the control group x $100 \%$. Tumors and internal organs (heart, liver, spleen, lung and liver) were fixed in formalin and processed for hematoxylineosin staining. The samples were processed by the following published standard methods. In brief, the sections $(4-5-\mu \mathrm{m})$ mounted on glass slides were deparaffinized, rehydrated through grated alcohols to distilled water, stained with hematoxylin and eosin, and then observed under a light microscope (Olympus BH-2).

\section{Results}

ESC-3 inhibits cell proliferation and colony-forming ability in human OvCa cell lines. To evaluate effects of ESC-3 on proliferation of A2780 cells using CCK-8 assays, A2780 cells were treated with ESC-3 at different concentrations (5, 10, 20, 40 and $80 \mu \mathrm{g} / \mathrm{ml}$ ) for 24,48 and $72 \mathrm{~h}$, respectively. As shown in Fig. 1A, after treated with different concentration of ESC-3, cell proliferation became slower compared to that of untreated cells $(\mathrm{P}<0.01)$. With ESC -3 concentrations 

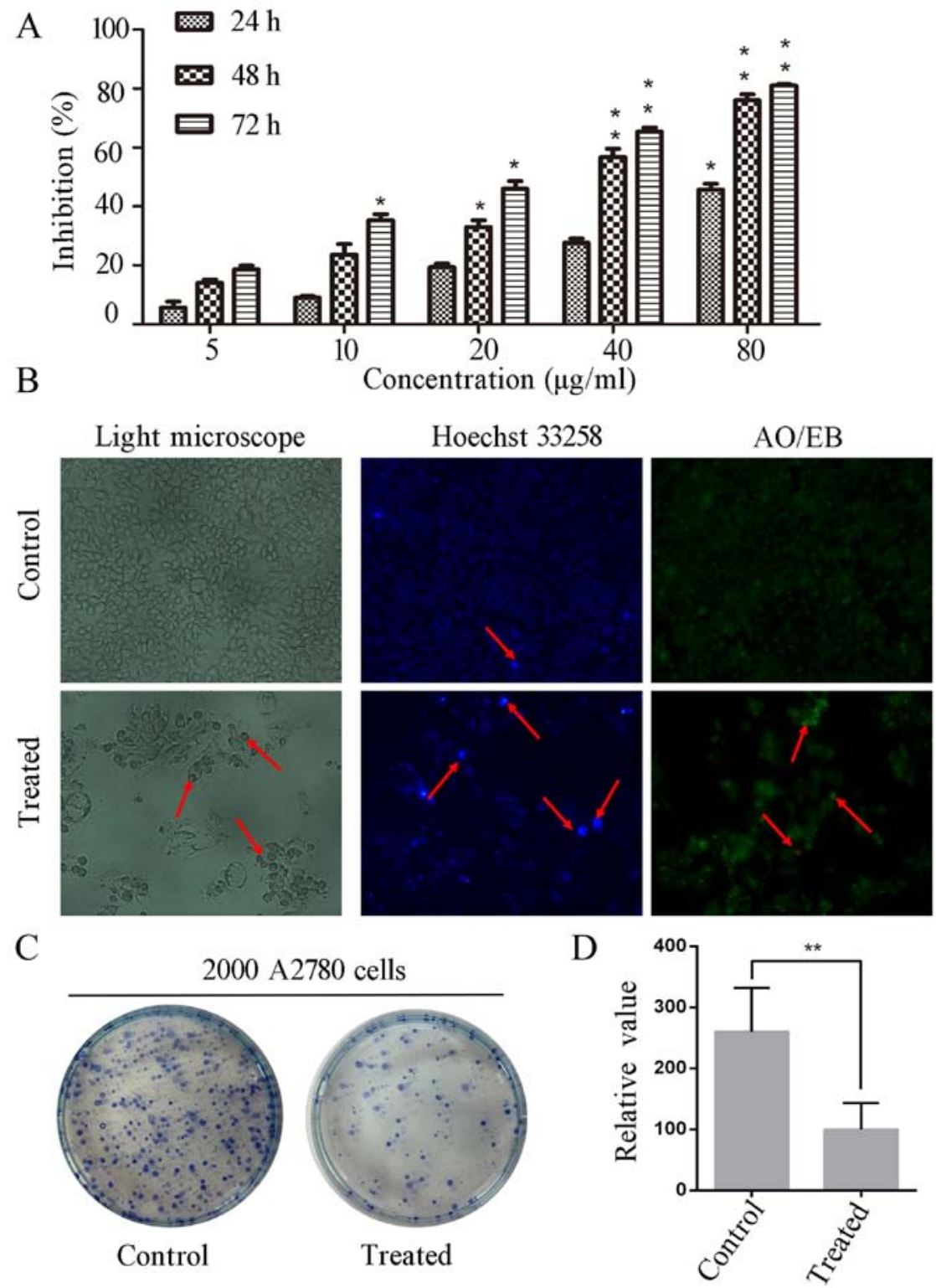

Figure 1. ESC-3 inhibited cell proliferation, colony-forming ability and induced morphological changes in A2780 cells. (A) After exposure to different concentrations of ESC-3 for various times (24, 48 and $72 \mathrm{~h}$ ) the proliferation of A2780 cells was measured by CCK8 assay. ${ }^{*} \mathrm{P}<0.05$ and ${ }^{* * *} \mathrm{P}<0.01$ compared with control group. (B) Morphological changes in the A2780 cells stained by Hoechst 33258 and AO/EB after exposure to different concentrations (0 and $40 \mu \mathrm{g} / \mathrm{ml}$ ). (C) Colony assay to detect the ability of colony-forming. In total 2,000 A2780 cells were seeded into culture dishes and stained with Giemsa after two weeks. (D) The quantification of colony number. ${ }^{*} \mathrm{P}<0.05$ and ${ }^{* *} \mathrm{P}<0.01$ compared with control group.

of $5,10,20,40$ and $80 \mu \mathrm{g} / \mathrm{ml}$ for $48 \mathrm{~h}$, the inhibition rates were 18, 22, 33, 57 and 76\%, respectively. Besides, ESC-3 significantly suppressed the proliferation of SKOV-3 cells and inhibited colony-formation ability as shown in Fig. 3A and G. After exposure to $60 \mu \mathrm{g} / \mathrm{ml}$ ESC-3, the changes in cell morphology occurred with typical trait of apoptosis: cell shrinkage, chromatin condensation, apoptotic body formation, dense nuclei (Fig. 3C). However, ESC-3 did not induce apoptosis in human ovarian carcinomas OVCAR-3 effectively (Fig. 3H). Our data indicated that ESC-3 could inhibit the proliferation of A2780 cells and SKOV-3 cells in a dose- and time-dependent manner.

To investigate whether morphological changes happened after ESC-3-treatment, we used an optical inverted microscope to visualized morphological features. As shown in
Fig. 1B, after treated with $40 \mu \mathrm{g} / \mathrm{ml}$ ESC-3, A2780 cells were smaller in size and close to rotundity compared to the control group. With Hoechst 33258 staining, the treated cells emitted a higher fluorescence intensity and were smaller than those of the control group in size. After AO/EB staining, the treated cells displayed orange and red fluorescence, while the untreated cells emitted a low green fluorescence in a homogeneous manner. To determine the ability of colony-forming, 2,000 A2780 cells were seeded into and treated with $40 \mu \mathrm{g} /$ ml ESC-3. As shown in Fig. 1C and D, the ESC-3-treated cells showed a significant decrease in colony number compared to the untreated A2780 cells. There results suggested that ESC-3treated A2780 cells displayed typical morphological features of apoptosis and a significant reduction in the colony-forming ability $(\mathrm{P}<0.01)$. 
A Concentration of ESC-3 $(\mu \mathrm{g} / \mathrm{ml})$
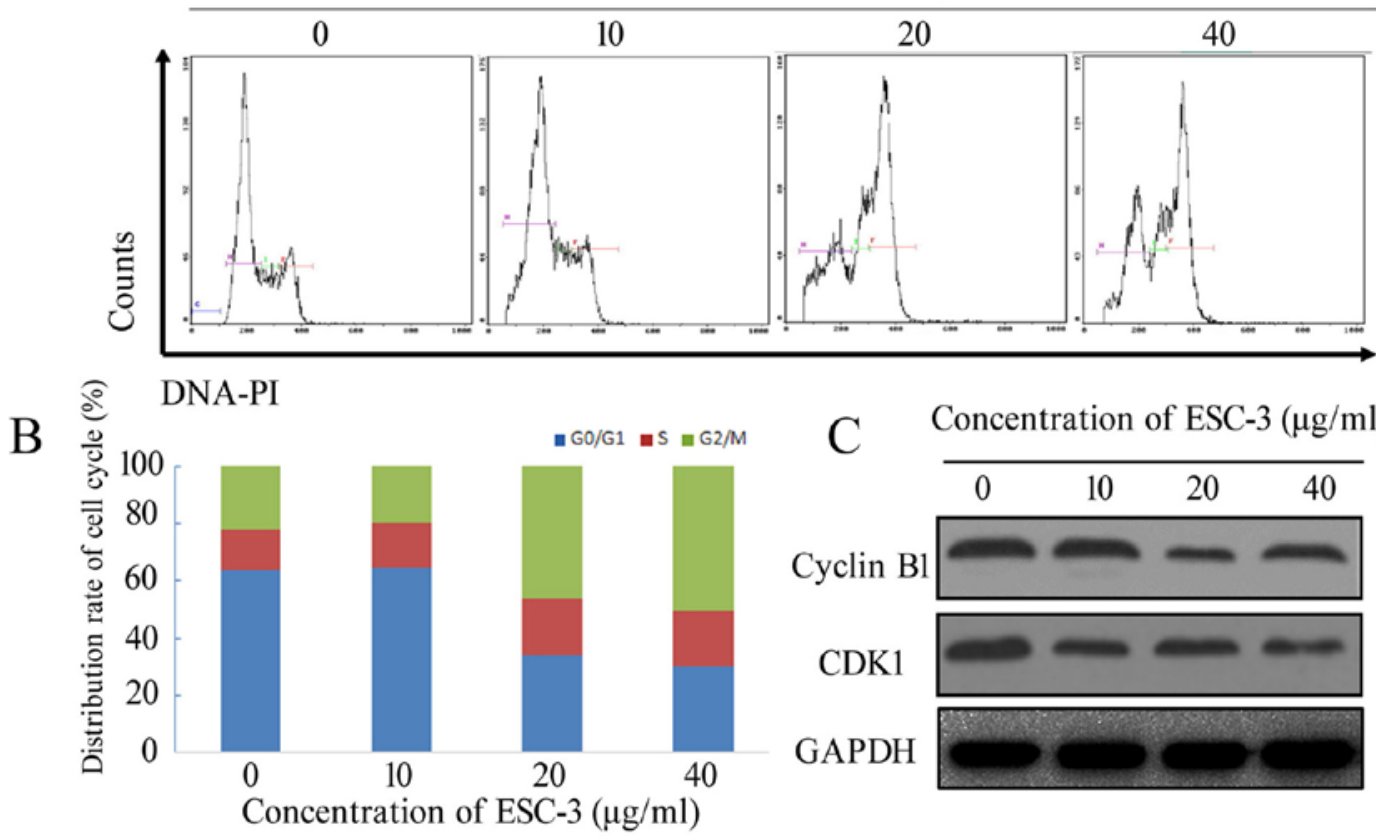

C Concentration of ESC-3 $(\mu \mathrm{g} / \mathrm{ml})$

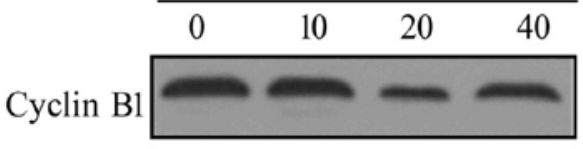

D

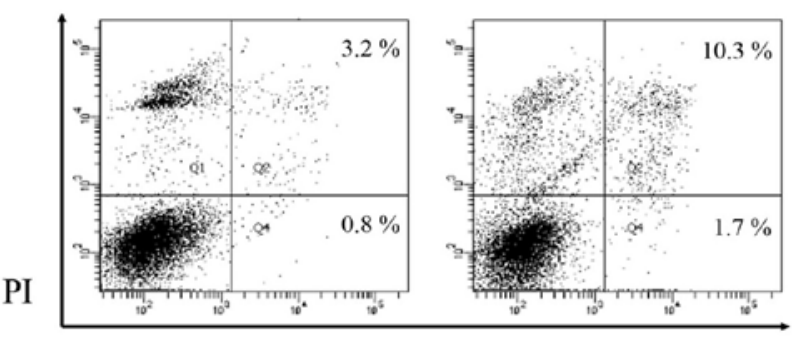

FITC

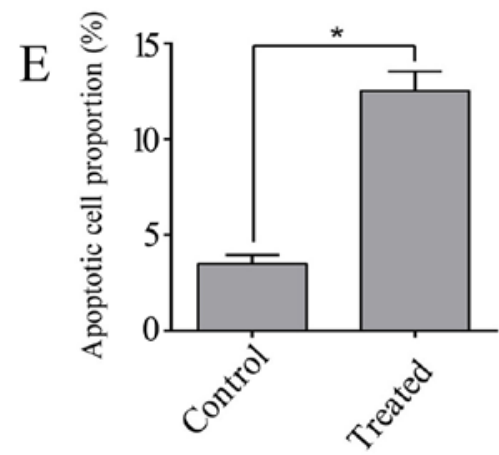

Figure 2. ESC-3 induces $\mathrm{G}_{2} / \mathrm{M}$ phase arrest and the elevation of apoptotic proportion compared to control group. (A) Cell lines were treated with ESC-3 for $48 \mathrm{~h}$, collected and fixed by $70 \%$ ethanol for $12 \mathrm{~h}$. Cell cycle was assessed with cytometry and Modfi LT. (B) The histogram illustrated the proportion of $\mathrm{G}_{0} / \mathrm{G}_{1}$ phase, $\mathrm{S}$ phase, $\mathrm{G}_{2} / \mathrm{M}$ phase after exposure to different concentrations of ESC-3. Error bars indicated the standard deviation ( $\mathrm{n}=3$ ). (C) Western blotting for cell lysis to analyse the expression of protein in regulating cell cycle after treated with different concentrations of ESC-3 for $48 \mathrm{~h}$. GAPDH served as a loading control. (D) Assessment of apoptosis using flow cytometry with staining by Annexin V-fluorescein isothiocyanate (V-FITC)/PI after exposure to $40 \mu \mathrm{g} / \mathrm{ml}$ ESC-3. (E) The quantification of cell apoptotic proportion. ${ }^{*} \mathrm{P}<0.05$ and ${ }^{* *} \mathrm{P}<0.01$ compared with control group.

ESC-3 causes cell cycle arrest and induces apoptotic cell death in $A 2780$ and SKOV3 cell lines. To confirm whether the inhibition of cellular proliferation was associated with the cell cycle distribution, we performed a cell cycle analysis after exposure to different concentration of ESC-3 (5, 10, 20, 40 and $80 \mu \mathrm{g} / \mathrm{ml}$ ). As shown in Fig. 2A and B, after treated with ESC-3 for $48 \mathrm{~h}$, the cell cycle distribution of A2780 cells was altered in a dose-dependent manner. The proportion of cells at the $\mathrm{G}_{2} / \mathrm{M}$ increased from 22.1 to $55.3 \%(\mathrm{P}<0.01)$, while the percentage of cells in $\mathrm{G}_{0} / \mathrm{G}_{1}$ phase was $63.8 \%$ in the control group and decreased to $30.3 \%$ after treatment with $40 \mu \mathrm{g} / \mathrm{ml}$ ESC-3 ( $\mathrm{P}<0.01)$. On the other hand, the proportion of ESC-3treated at $\mathrm{S}$ phase displayed non-significance compared to untreated cells. ESC-3 caused cell cycle arrest and induced apoptotic cell death in SKOV-3, which could confirm the consistency of the in vitro study in A2780 cells as shown in Fig. 3E. Our data indicated that ESC-3 arrested A2780 cells and SKOV-3 cells at $\mathrm{G}_{2} / \mathrm{M}$ phase and suppressed cell proliferation. The protein level of CDK1 and cyclin B1 were decreased after exposure to ESC-3 compared with the untreated group in A2780 cells (Fig. 2C).

We preformed flow cytometric analysis using dual staining with Annexin $\mathrm{V}$ and propidium iodide to distinguish between early apoptotic and late apoptotic cells. As shown in Fig. 2D and $\mathrm{E}$, the apoptotic proportion of cells with $40 \mu \mathrm{g} / \mathrm{ml}$ was $13.5 \%$ compared to untreated cells with $2.5 \%$ apoptotic proportion $(\mathrm{P}<0.05)$. Therefore, we demonstrated that apoptosis could be induced by ESC-3.

ESC-3 induces A2780 apoptotic cell death through Wnt/ $\beta$ catenin and Notch pathway. To investigate the apoptosis mechanism induced by ESC-3, the expression of apoptosisrelated (Bax, Bcl-2 and P53) and pathway-related (Wnt2, $\beta$-catenin, Notch1, Notch2 and Hes1) proteins were measured by western blotting and quantified using ImageJ software. As shown in Fig. 4A and B, the proteins level of Bax were significantly increased $(\mathrm{P}<0.01)$ after exposure to ESC-3 for $24 \mathrm{~h}$, while the change in expression of $\mathrm{Bcl}-2$ proteins remained 


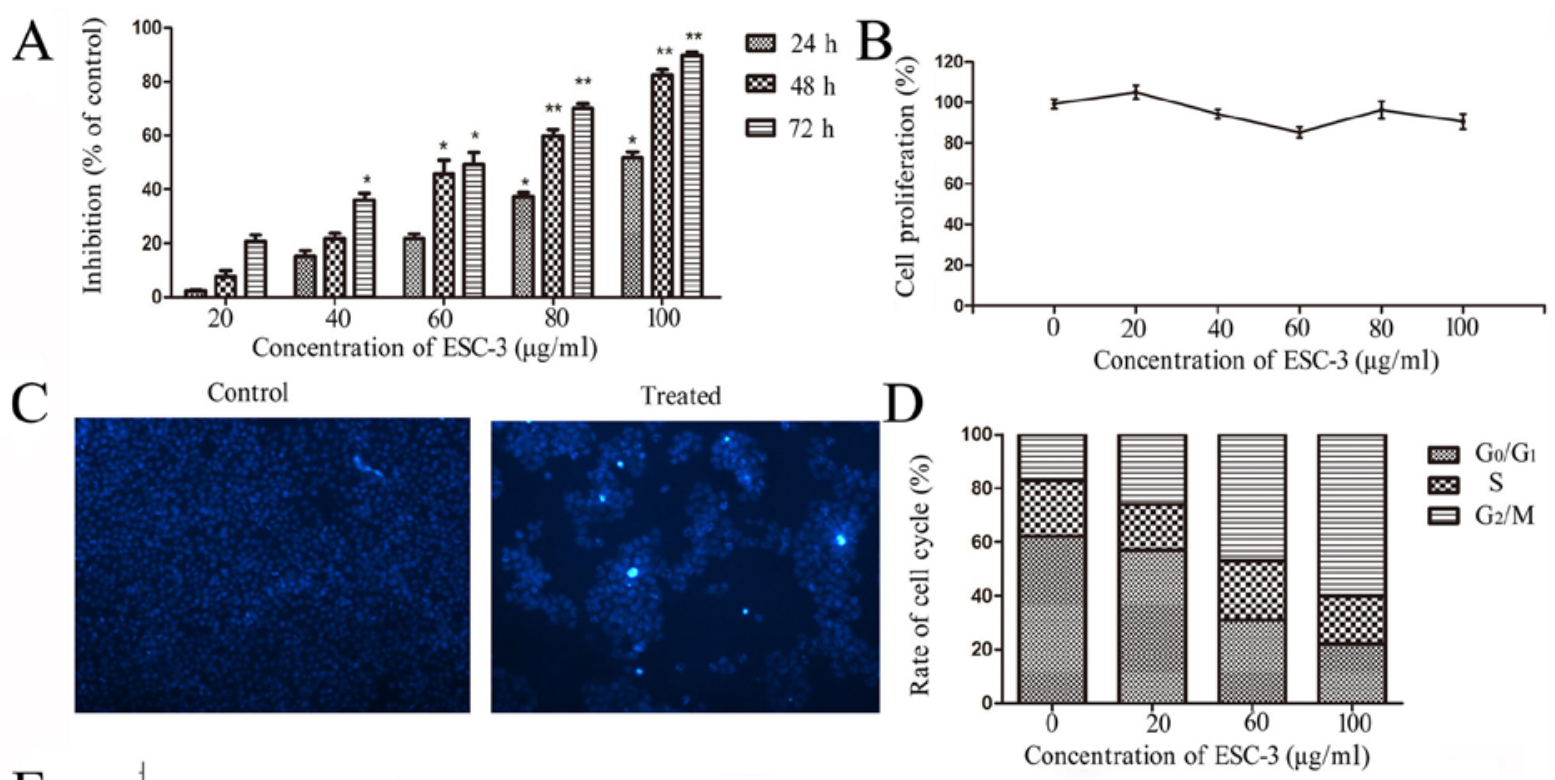

$\mathrm{E}$
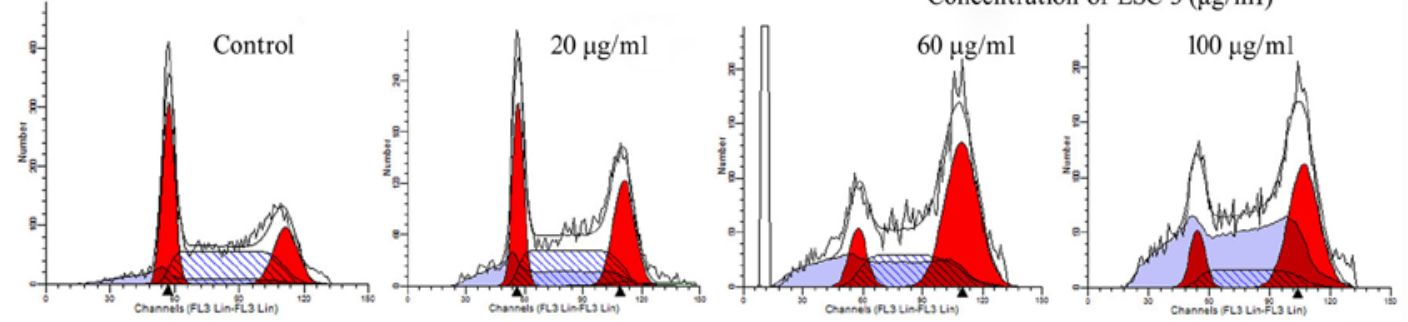

$\mathrm{F}$
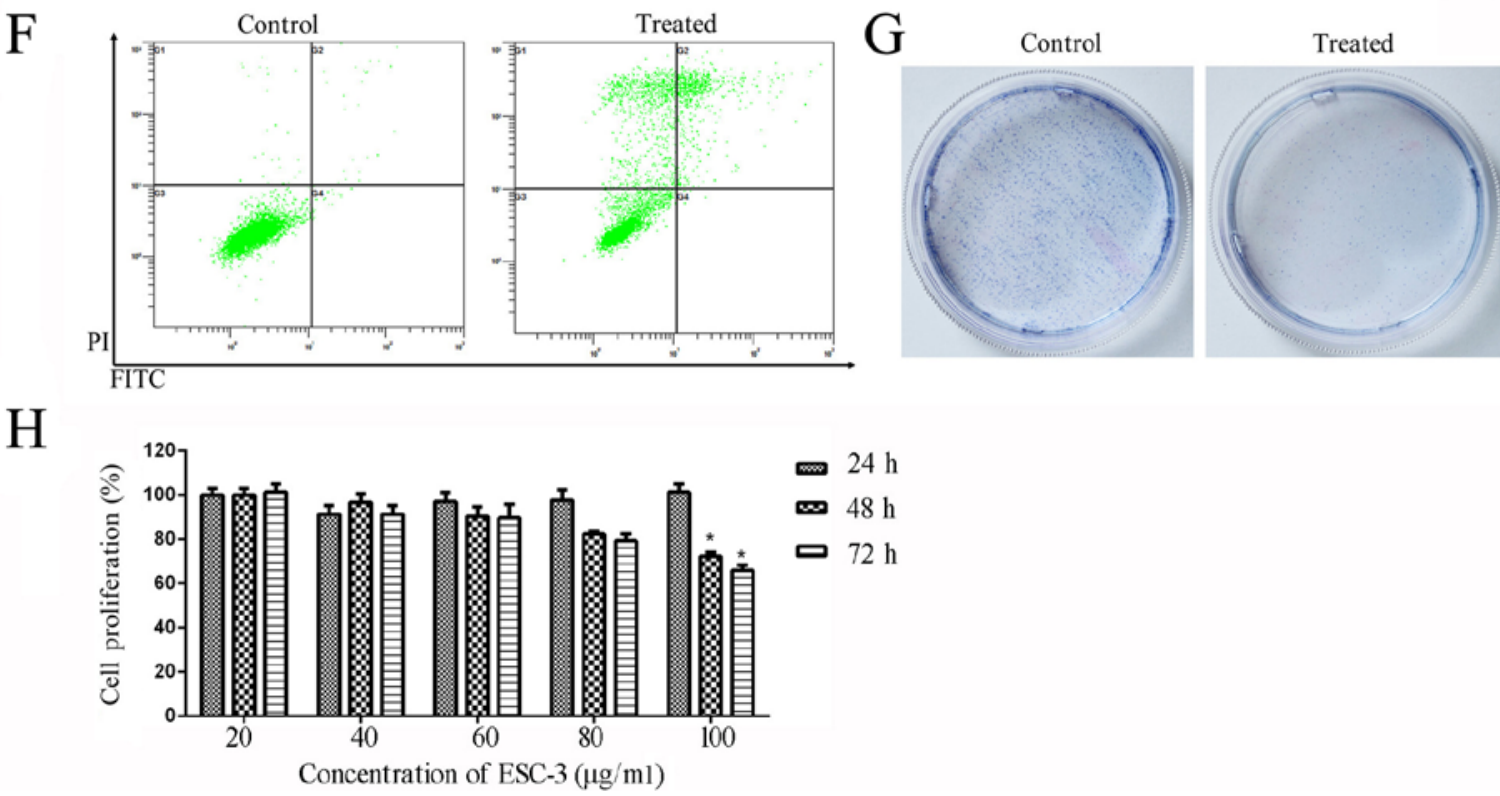

Figure 3. ESC-3 inhibits cell proliferation, colony-forming ability and induces morphological changes in SKOV-3 cells. (A) After exposure to different concentrations of ESC-3 for various time (24, 48 and $72 \mathrm{~h}$ ) the proliferation of SKOV-3 cells was measured by CCK8 assay. (B) After exposure to different concentrations of ESC-3 for $48 \mathrm{~h}$, the proliferation of IOSE- 80 cells was measured by CCK8 assay. (C) Morphological changes in the SKOV-3 cells stained by Hoechst 33258 after exposure to different concentrations $(0$ and $60 \mu \mathrm{g} / \mathrm{ml})$. (D) The histogram illustrates the proportion of $\mathrm{G}_{0} / \mathrm{G}_{1}$ phase, $\mathrm{S}$ phase, $\mathrm{G}_{2} / \mathrm{M} \mathrm{phase}$ after exposure to different concentrations of ESC-3. Era bars indicated the standard deviation ( $\mathrm{n}=3$ ). (E) Cell lines were treated with ESC-3 for $48 \mathrm{~h}$, collected and fixed by $70 \%$ ethanol for $12 \mathrm{~h}$. Cell cycle was assessed with cytometry and Modfi LT. (F) Assessment of apoptosis using flow cytometry with staining by Annexin V-fluorescein isothiocyanate (V-FITC)/PI after exposure to $60 \mu \mathrm{g} / \mathrm{ml}$ ESC-3. (G) Colony assay to detect the ability of colony-forming. In total 2,000 SKOV-3 cells were seeded into culture dishes and stained by Giemsa after two weeks. (H) After exposure to different concentrations of ESC-3 for various time $(24,48$ and $72 \mathrm{~h})$, the proliferation of OVCAR-3 cells was measured by CCK 8 assay.

non-significant; therefore, the ratio of Bax to Bcl-2 increased $(\mathrm{P}<0.01)$ significantly compared to the untreated group. Moreover, the protein levels of P53 were remarkably increased in a dose-dependent manner. As shown in Fig. 4E and F, the expression of Wnt2 proteins were decreased to $65 \%$ protein levels of the untreated group, and the expression of $\beta$-catenin at the protein levels decreased $(\mathrm{P}<0.01)$ significantly compared the proteins obtained from the untreated cells. Besides, the 


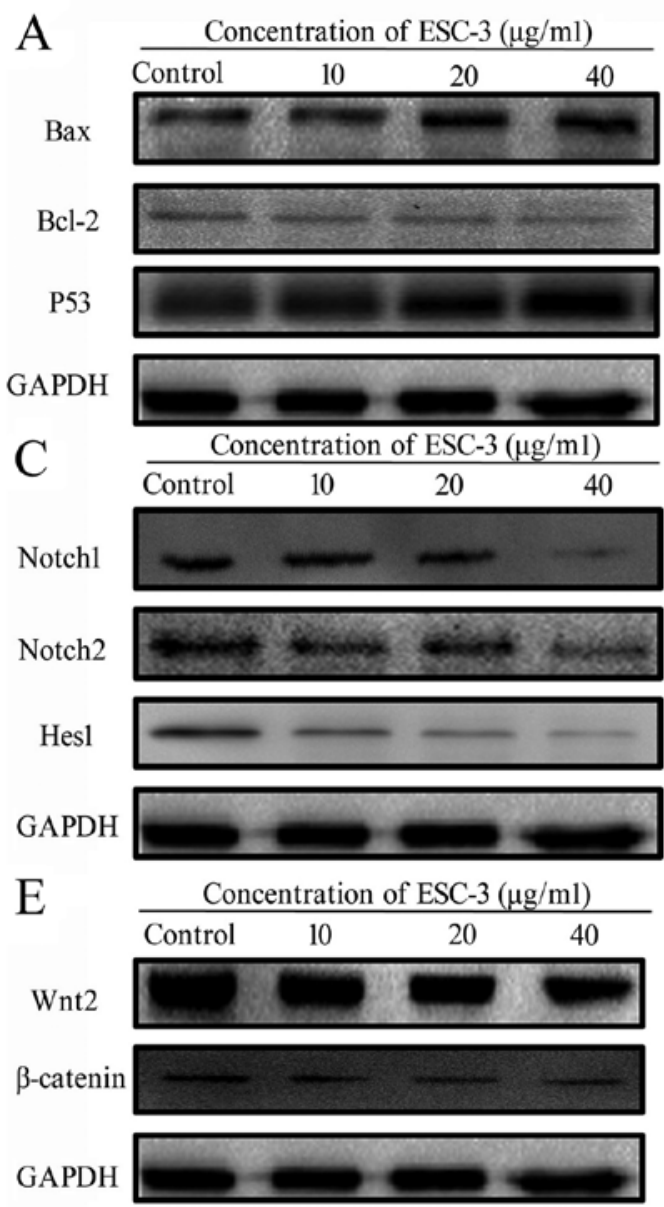

B

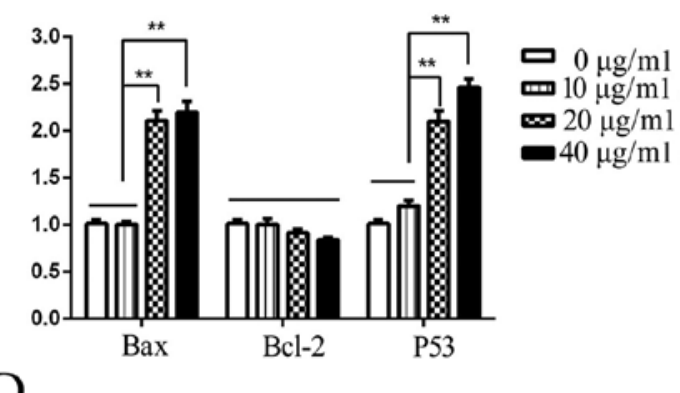

$\mathrm{D}$

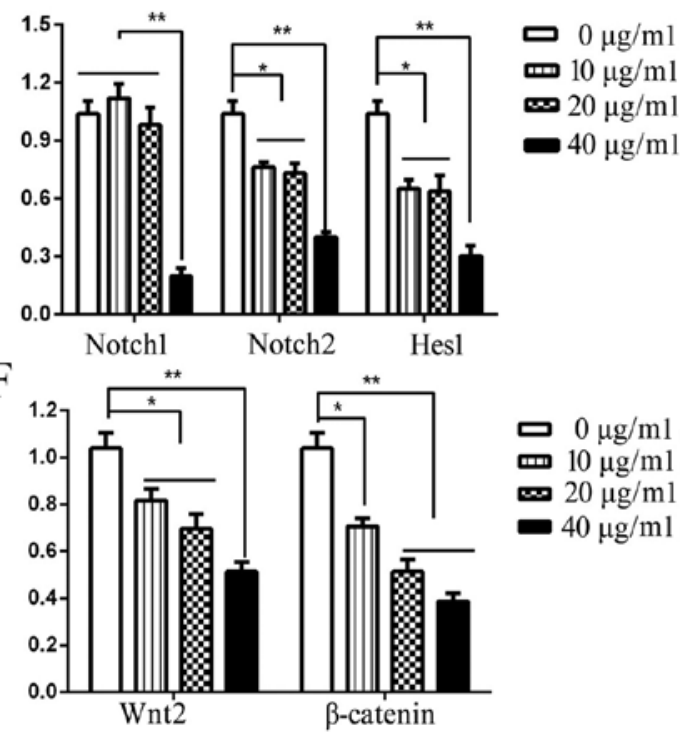

Figure 4. Apoptosis induced by ESC-3 through Wnt/ $\beta$-catenin and Notch signaling in vitro. (A, C and E) Western blotting for cell lysis collected to analyse the expression of apoptosis- and signaling-related proteins after treated with different concentrations $(0,10,20$ and $40 \mu \mathrm{g} / \mathrm{ml})$ of ESC-3 for $48 \mathrm{~h}$. (B, D and F) The histogram illustrate the quantified results of apoptosis and signaling-related proteins after treated with different concentrations $(0,10,20$ and $40 \mu \mathrm{g} / \mathrm{ml})$ of ESC-3 for 48 h. ${ }^{*} \mathrm{P}<0.05$ and ${ }^{* *} \mathrm{P}<0.01$ compared with control group.

expression of Notch1 and Notch2 proteins, the receptor located at cell membrane initiating the Notch pathway, decreased significantly $(\mathrm{P}<0.01)$ in a dose-dependent manner; the expression levels of the Hes1 proteins, the downstream proteins of Notch pathway, decreased $(\mathrm{P}<0.01)$ obviously (Fig. 3C and D). Our data suggested that the Wnt//-catenin and Notch pathway might play a significant role in induction of cell apoptosis by ESC-3.

ESC-3 inhibits the growth of A2780 xenograft tumor in Balb/c nude mice without noticeable toxicity. To determine the antitumor effects of ESC-3, $1 \times 10^{6}$ A2780 cells were injected subcutaneously into the right flank of Balb/c nude mice to build the tumor xenograft models as shown in Fig. 5A. During the study, the body weight and tumor volume of nude mice was tracked every three days to detect the non-toxic and effectivity of ESC-3 in vivo. As shown in Fig. 5D and E, the body weight of nude mice treated with ESC-3 displayed non-significant changes compared to the control group, while the volume demonstrated apparent difference between the treated and the control group (at the 15 th day $\mathrm{P}<0.05$ and at the 21st day $\mathrm{P}<0.01$ ). After administration (i.g) with ESC-3 for 24 days, the mice were sacrificed (Fig. 5B) and the tumors
Table I. Evaluation system of ESC-3 on ovarian xenograft models.

\begin{tabular}{lcccc}
\hline & $\begin{array}{c}\text { Mean volume } \\
(\mathrm{t}=0)\end{array}$ & $\begin{array}{c}\text { Mean volume } \\
(\mathrm{t}=24)\end{array}$ & $\mathrm{RTV}$ & $\mathrm{T} / \mathrm{C}$ \\
\hline $\begin{array}{l}\text { Control } \\
\text { group }\end{array}$ & $95.53 \mathrm{~mm}^{3}$ & $1,323.32 \mathrm{~mm}^{3}$ & 13.85 & \\
$\begin{array}{l}\text { Treated } \\
\text { group }\end{array}$ & $91.61 \mathrm{~mm}^{3}$ & $545.04 \mathrm{~mm}^{3}$ & 5.95 & $42 \%$ \\
\hline
\end{tabular}

$\mathrm{RTV}$, relative tumor volume; $\mathrm{RTV}=\mathrm{TV}_{\mathrm{n}} / \mathrm{TV}_{0}$, where $\mathrm{TV}_{\mathrm{n}}$ is the tumor volume at day $\mathrm{n}$ and $\mathrm{TV}_{0}$ is the tumor volume at day 0 . Therapeutic effects were expressed in terms of $\mathrm{T} / \mathrm{C}(\%)$ using the calculation formula $\mathrm{T} / \mathrm{C}(\%)=$ mean RTV of the treated group/mean RTV of the control group x $100 \%(\mathrm{n}=8)$.

was excised (Fig. 5C) and weighed (Fig. 5F), the tumors from ESC-3-treated mice were smaller and lighter than those of the control group $(\mathrm{P}<0.01)$. As shown in Fig. 5G, hematoxylineosin staining of ESC-3-treated pathological paraffin sections 
A

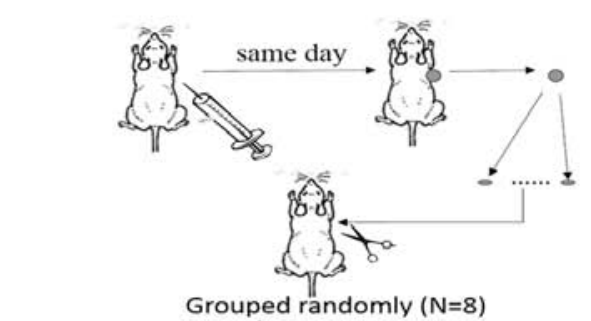

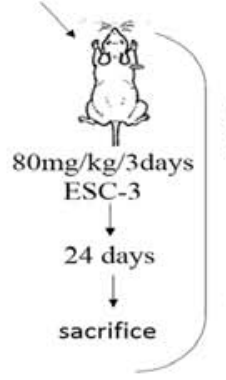
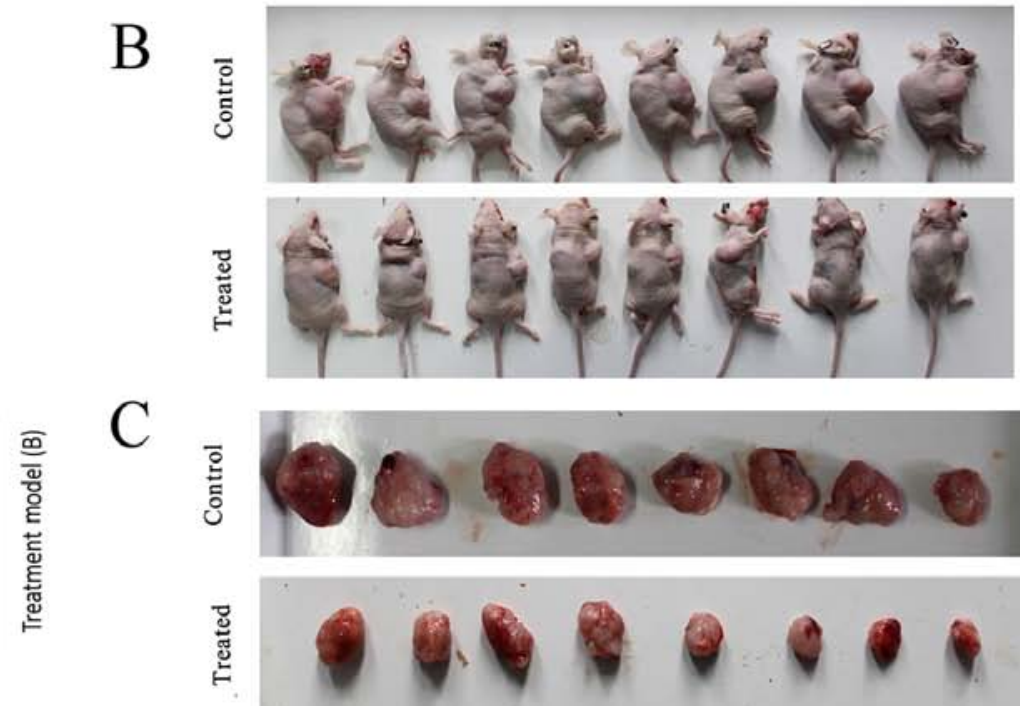

$\mathrm{C}$
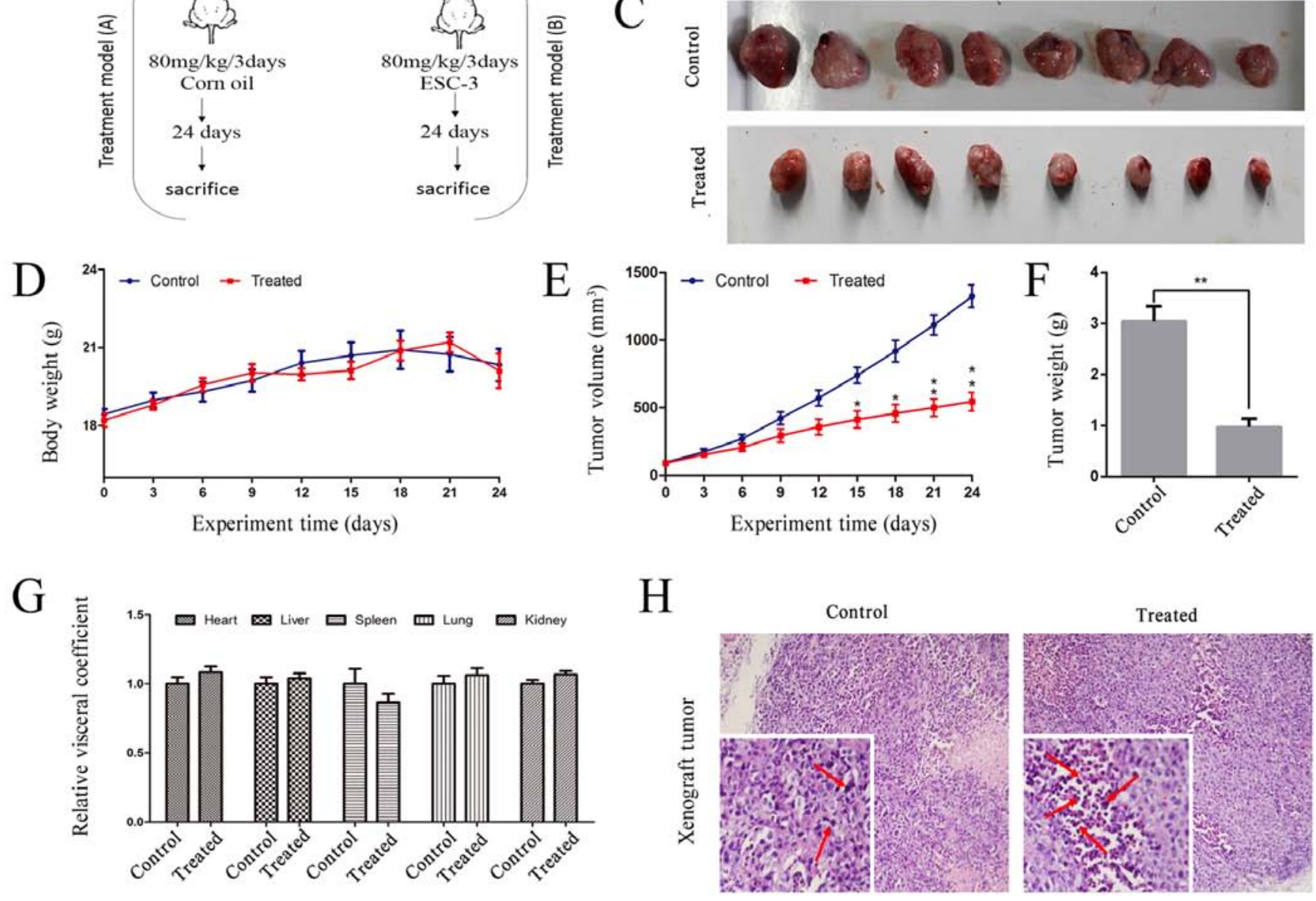

I
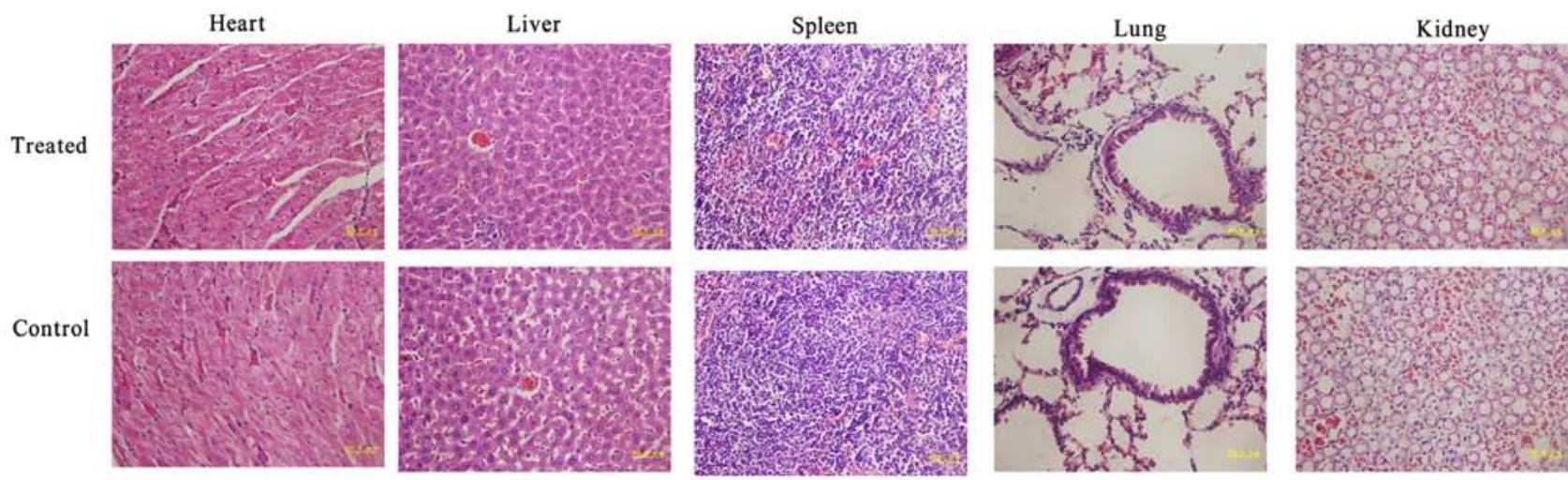

Figure 5. ESC-3 suppresses the growth of tumor in xenograft models without toxicity to viscera. (A) The flow chart of xenograft models. Approximately $5 \times 10^{6}$ A2780 cells were subcutaneously injected into nude mice to generate a tumor which was transplanted in $16 \mathrm{Balb} / \mathrm{b}$ nude mice equally. When the tumor reach the volume of $100 \mathrm{~mm}^{3}$, the mice were grouped and administered (i.g) with corn oil (control group) and $80 \mathrm{mg} / \mathrm{kg}$ ESC-3 (treated group) every three days. After 24 days, the mice were sacrificed and the tumors were excised for the following study. (B) Balb/c nude mice with solid tumors. (C) Solid tumor excised from Balb/c nude mice. (D) The variational curve of nude mouse body weight. (E) Mean tumor volume measured by caliper on the indicated days. "P<0.05 and ${ }^{* *} \mathrm{P}<0.01$ compared with control group. (F) Mean tumor weight at the end of 24 days. ${ }^{*} \mathrm{P}<0.05$ and ${ }^{* *} \mathrm{P}<0.01$ compared with control group. (G) Relative visceral efficient after administration (i.g.) of corn oil and $80 \mathrm{mg} / \mathrm{kg}$ ESC-3 every three days respectively. (H) Pathological paraffin sections of a tumor stained with hematoxylin-eosin staining. (I) Pathological paraffin sections of viscera stained with hematoxylin-eosin staining. 
Table II. Weight of nude mouse body, tumor and viscera at the 24th day.

\begin{tabular}{cccccccc}
\hline No. & Heart & Liver & Spleen & Lung & Kidney & Body & Tumor \\
\hline 1 & 0.0914 & 1.5033 & 0.2346 & 0.1227 & 0.3212 & 21.5 & 4.1511 \\
2 & 0.1115 & 1.3387 & 0.1555 & 0.1273 & 0.3929 & 22.7 & 2.2685 \\
3 & 0.1158 & 1.4238 & 0.1171 & 0.1310 & 0.3031 & 17.2 & 1.6610 \\
4 & 0.0983 & 1.3953 & 0.1316 & 0.1445 & 0.3381 & 19.5 & 3.0444 \\
5 & 0.1156 & 1.3570 & 0.2425 & 0.1993 & 0.3298 & 21.8 & 2.8495 \\
6 & 0.1055 & 1.1678 & 0.1108 & 0.1370 & 0.3011 & 21.1 & 3.8889 \\
7 & 0.1061 & 1.3355 & 0.1233 & 0.1321 & 0.3055 & 19.5 & 2.9054 \\
8 & 0.0965 & 1.1336 & 0.1064 & 0.1497 & 0.2968 & 19.3 & 3.6030 \\
Mean & 0.1051 & 1.3319 & 0.1527 & 0.1430 & 0.3236 & 20.3 & 3.0465 \\
9 & 0.1246 & 1.3500 & 0.1402 & 0.1650 & 0.3457 & 22.3 & 0.4304 \\
10 & 0.1090 & 1.4654 & 0.1072 & 0.1266 & 0.3446 & 21.1 & 1.3244 \\
11 & 0.1125 & 1.3435 & 0.1322 & 0.1499 & 0.3332 & 20.9 & 0.6967 \\
12 & 0.1203 & 1.5170 & 0.1361 & 0.1841 & 0.3503 & 21.8 & 1.2925 \\
13 & 0.0913 & 1.2272 & 0.1514 & 0.1161 & 0.3252 & 18.1 & 0.4968 \\
14 & 0.1128 & 1.4028 & 0.1710 & 0.1651 & 0.3587 & 20.3 & 1.6308 \\
15 & 0.1186 & 1.4050 & 0.1023 & 0.1520 & 0.3124 & 16.8 & 1.3545 \\
16 & 0.1147 & 1.2606 & 0.0899 & 0.1454 & 0.3535 & 19.5 & 0.5738 \\
Mean & 0.1130 & 1.3734 & 0.1288 & 0.1505 & 0.3405 & 20.1 & $0.9750^{\mathrm{b}}$ \\
\hline
\end{tabular}

${ }^{\mathrm{a}} \mathrm{P}<0.05,{ }^{\mathrm{b}} \mathrm{P}<0.01$ compared to the control group ( $\left.\mathrm{n}=8\right)$. Control group numbered 1-8 (every three days, i.g. $100 \mu 1$ corn oil). Treated numbered 9-16 (every three days, i.g. $100 \mu 180 \mathrm{mg} / \mathrm{kg}$ ESC-3).

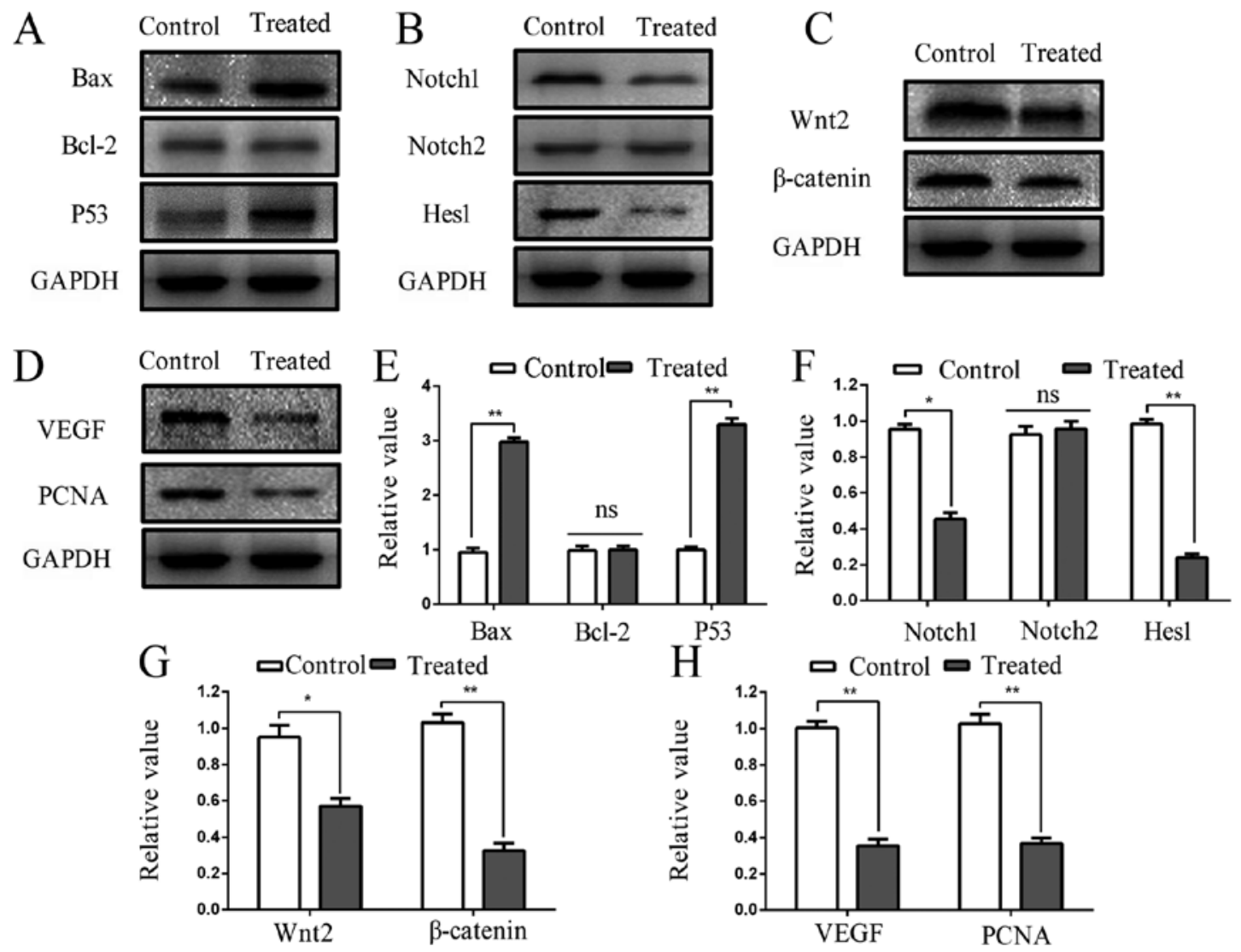

Figure 6. Xenograft model displays the consistency in apoptotic mechanism at protein levels. (A-C) Western blotting for tumor lysis to confirm the expression of apoptosis- and signaling-related proteins. GAPDH served as a loading control. (D) Western blotting of tumor lysis to measure the protein levels of PCNA and VEGF. (E-H) The bar graph illustrates the quantification of signaling-related proteins. ${ }^{*} \mathrm{P}<0.05$ and ${ }^{* *} \mathrm{P}<0.01$ compared with control group. Values are expressed as the means \pm SEM, $n=3$ parallel experiments in each group. 


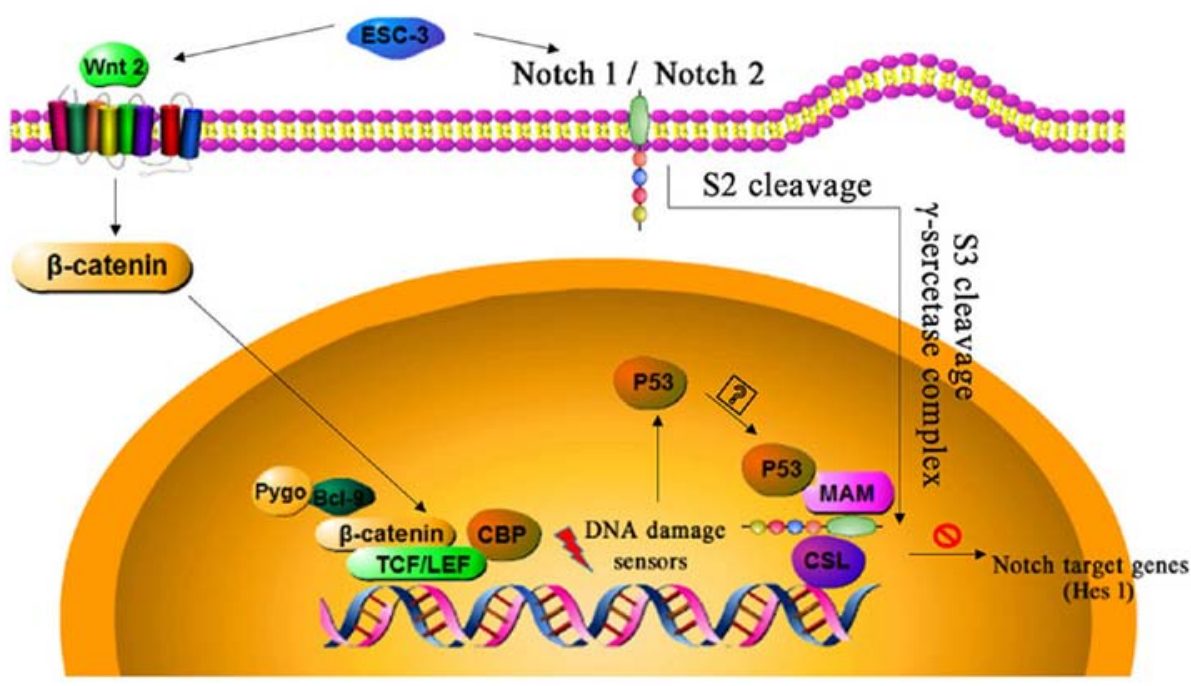

Figure 7. Illustration of apoptotic signaling induced by ESC-3 in OvCa.

displayed typical apoptotic features: condensed chromatin and pyknotic nuclei. To confirm the non-toxicity of ESC-3 further, the viscus of Balb/c nude mice were excised, weight and stained with hematoxylin-eosin, it showed that the relative visceral coefficient have no remarkable difference between the control group and ESC-3-treated group (Fig. 5H), and hematoxylin-eosin staining of ESC-3-treated viscus pathological paraffin sections displayed no significant changes in organizational structure (Fig. 5I). Our data demonstrated that ESC-3 effectively suppressed the growth of A2780 xenograft tumors $(\mathrm{T} / \mathrm{C}=42 \%)$ without affecting the weight and viscus of nude mice as shown in Tables I and II. Therefore, the ESC-3 is efficient and non-toxic to ovarian cancer.

Tumor inhibition is induced by ESC-3 through Wnt/ $\beta$-catenin and Notch pathway. After tumors were treated (i.g) with $80 \mathrm{mg} / \mathrm{kg}$ ESC-3 every three days for 24 days, the expression of proteins obtained from the tumors were measured by western blot analyses to determine the consistency of the results in vitro and in vivo. We examined the expression levels of apoptosis-related and pathway-related proteins, including Bax, Bcl-2, P53, Wnt2, $\beta$-catenin, Notch1, Notch2, Hes1, VEGF and PCNA. As shown in Fig. 6A and E, the result of western blot analyses revealed that the expression of Bax was significantly increased 2 .9-fold $(\mathrm{P}<0.01)$ after administration (i.g) with ESC-3, while proteins of Bcl-2 remained about the same compared to the control group; therefore, the ratio of Bax to Bcl-2 also increased $(\mathrm{P}<0.01)$. Moreover, we observed that the levels of P53 proteins obtained from ESC-3-treated increased $\sim 3.3$-fold $(\mathrm{P}<0.01)$, which displayed the consistency also observed in vitro and in vivo. Furthermore, we determined the proteins in $\mathrm{Wnt} / \beta$-catenin and Notch pathway, as shown in Fig. 6B and F, the expression of Notch1 and Notch2 proteins decreased $\sim 1.21$-fold $(\mathrm{P}<0.05)$ and 0.06-fold respectively, the proteins level of Hes1, the downstream effector proteins of Notch pathway, were decreased $(\mathrm{P}<0.01)$ significantly after administration (i.g) of ESC-3 for 24 days. ESC-3 has a significant effect on the expression levels of Wnt 2 and $\beta$-catenin proteins based on the ESC-3-treated tumors (Fig. 6C and G). Furthermore, the expression of VEGF and PCNA were significantly decreased at the protein level compared with the control group (Fig. 6D and H).

\section{Discussion}

Apoptosis, programmed cell death under physiological or pathological conditions, plays a critical role in the tissue homeostasis of eukaryotes (11). It is desirable to prevent the occurrence and metastasis of cancer through inducing apoptosis (12). The cancer cells have the ability to sustain chronic proliferation through the cell cycle, which is the most fundamental feature (13). Our data were suggested that ESC-3 significantly suppressed the proliferation of A2780 cells and inhibited colony-formation ability. After exposure to different concentrations of ESC-3, the A2780 cells were arrested at $\mathrm{G}_{2} / \mathrm{M}$ phase through downregulation of CDK1 and cyclin B1, two critical $\mathrm{G}_{2} / \mathrm{M}$ transition regulators (14). The primary indicators of apoptosis under physiological and pathological conditions, are the morphological changes $(11,15,16)$. After exposure to $40 \mu \mathrm{g} / \mathrm{ml} \mathrm{ESC}-3$, the changes in cell morphology occurred with typical trait of apoptosis: cell shrinkage, chromatin condensation, apoptotic body formation, and dense nuclei. Our results were in agreement with the study by Horowitz et al (17), concluding that chenodeoxycholic acid (CDCA) and deoxycholic acid (DCA) possess the ability to induce apoptotic phenomenon in ovarian cancers. Then, SKOV-3 and OVCAR-3 cell lines were analyzed in vitro. The results suggested that ESC-3-treated SKOV-3 cells displayed typical morphological features of apoptosis and a significant reduction in the colonyforming ability. Besides, ESC-3 caused cell cycle arrest and induced apoptotic cell death in SKOV-3, which confirmed the consistency with the in vitro study in A2780 cells. However, ESC-3 did not induce apoptosis in human ovarian carcinomas OVCAR-3 effectively, this difference in suppression of ESC-3 on A2780, SKOV-3 and OVCAR-3 cell proliferation confirmed the different phenotypes of these three ovarian cancer cell 
lines, which emphasizes the need to recognize the heterogeneity of cancer cell populations (18-21). Furthermore, we used normal human ovarian epithelial cells (IOSE-80) to perform the CCK- 8 assay. We found that, compared to the control, ESC-3 dose-dependently inhibited A2780 cells and SKOV-3 cells, but not IOSE-80 in cell proliferation as shown in Figs. 1A and $3 \mathrm{~A}$ and $\mathrm{B}$.

The Bcl-2 family plays a vital role in regulating of apoptosis, including $\mathrm{Bax}$ and $\mathrm{Bcl}-2$, of which the former induces apoptosis and the latter prevents apoptosis (22). In the present study, our data demonstrated that ESC-3 could significantly upregulate the expression of Bax proteins while the protein levels of $\mathrm{Bcl}-2$ remained steady, resulting in the elevation of $\mathrm{Bax} / \mathrm{Bcl}-2$ ratio which usually induces apoptosis (23). In the previous study, bile extract from crocodile could induce apoptosis in human cholangiocarcinoma through the mitochondrial pathway (24). Furthermore, ESC-3 isolated from Crocodylus siamensis bile through a Sephadex LH-20 column (Pharmacia, Sweden) and an RP-18 reversed-phase column $(25 \times 0.3 \mathrm{~cm})$, induced apoptosis in $\mathrm{Mz}-\mathrm{ChA}-1$ cells in a dose-dependent manner via the mitochondria-dependent pathway (9). In this study, we demonstrated the mechanism of apoptosis induced by ESC-3 in human OvCa carcinomas. The development and progression of several malignancies have association with the Notch signal pathway $(25,26)$. There are four Notch receptors the Notch1, 2, 3 and 4 and five ligands (Delta-like1, 3 and 4) in Notch signaling mediating via cell-to-cell contact (27). A basic platform consisting of the ternary complex (Notch-CSL-MAM) could recruit coactivators including p300 to increasing the expression levels of Notch pathway downstream proteins (28-30), however, this process could be blocked with the abnormal elevation of P53, a tumor suppressor in human cancers (31). Our results suggested that ESC-3 could significantly $(\mathrm{P}<0.01)$ upregulate the expression of P53, while hes1 remarkably decreased at the proteins levels. As previous research reported that Hes1, the downstream protein of Notch pathway, could be suppressed by the abnormal elevation of P53 through the combination with Notch-CSL-MAM complex, which might disturb the tendency of dose-response at the protein level (31). Our data do not indicate whether the association between p53 and the NTCs is mediated by direct association with MAM or through additional proteins. However, it was reported that P53 can be combination with MAM directly to block the recruitment of a coactivator. The associations between Wnt signaling and ovarian cancer confirmed that Wnt signaling played a critical role in the embryonic development of ovary and homeostasis including proliferation, differentiation, and migration $(32,33)$. Our data suggested that ESC-3 could downregulate the expression of Wnt2 at the protein levels, whereas, the protein levels of $\beta$-catenin, the key effector in Wnt signaling, were decreased $(\mathrm{P}<0.01)$ significantly. In conclusion, ESC-3 induced apoptosis of human ovarian carcinomas through Wnt/ $\beta$-catenin and Notch signaling as shown in Fig. 7.

The xenograft models were employed to confirm the consistency with the in vitro assays and to determine the non-toxicity and effectiveness of ESC-3. Our data in vivo demonstrated that $80 \mathrm{mg} / \mathrm{kg}$ dose of ESC-3 every three days was highly effective and did not have toxic side effects. ESC-3 also effectively inhibited the expression of the proliferation marker PCNA (34), indicating its important role in the growth of ovarian tumors. Furthermore, the expression of vascular endothelial growth factor (VEGF), playing a critical role in angiogenesis (proliferation, migration and survival of endothelial cells) in cancer $(35,36)$, was significantly decreased measured by western blotting. The molecular mechanism demonstrated the consistency between result in vitro and in vivo after treated with ESC-3. Therefore, our data suggested that ESC-3 was a safe, natural and effective compound in ovarian cancer therapy.

In conclusion, ESC-3 is a novel active compound that could arrest the A2780 cells and SKOV-3 cells at the $\mathrm{G}_{2} / \mathrm{M}$ phase and cyclin B1 proteins and induce apoptosis in a dose-dependent manner via the Wnt/ $\beta$-catenin and Notch pathway, moreover, xenograft models displayed the consistency as showed in the results in vitro. Therefore, ESC-3 could be a potential therapeutic in ovarian carcinomas.

\section{Acknowledgements}

This study was supported by the Natural Science Foundation of China (grant nos. 81571418 and 81402309), the National Science Foundation for Fostering Talents in Basic Research of the National Natural Science Foundation of China (grant no. J1310027) and by the Natural Sciences Foundation of Fujian Province, China (2016J05105).

\section{References}

1. Seidman JD, Horkayne-Szakaly I, Haiba M, Boice CR, Kurman RJ and Ronnett BM: The histologic type and stage distribution of ovarian carcinomas of surface epithelial origin. Int J Gynecol Pathol 23: 41-44, 2004.

2. Siegel R, Ma J, Zou Z and Jemal A: Cancer statistics, 2014. CA Cancer J Clin 64: 9-29, 2014.

3. Vaughan S, Coward JI, Bast RC Jr, Berchuck A, Berek JS, Brenton JD, Coukos G,Crum CC,Drapkin R,EtemadmoghadamD, et al: Rethinking ovarian cancer: Recommendations for improving outcomes. Nat Rev Cancer 11: 719-725, 2011.

4. Matsuo K, Lin YG, Roman LD and Sood AK: Overcoming platinum resistance in ovarian carcinoma. Expert Opin Investig Drugs 19: 1339-1354, 2010.

5. Wang Y and Morrow JS: Identification and characterization of human SLP-2, a novel homologue of stomatin (band 7.2b) present in erythrocytes and other tissues. J Biol Chem 275: 8062-8071, 2000.

6. Tint GS, Dayal B, Batta AK, Shefer S, Joanen T, McNease L and Salen G: Biliary bile acids, bile alcohols, and sterols of Alligator mississippiensis. J Lipid Res 21: 110-117, 1980.

7. Yeh YH, Wang DY, Liau MY, Wu ML, Deng JF, Noguchi T and Hwang DF: Bile acid composition in snake bile juice and toxicity of snake bile acids to rats. Comp Biochem Physiol C Toxicol Pharmacol 136: 277-284, 2003.

8. Song W, Li SS, Qiu PP, Shen DY, Tian L, Zhang QY, Liao LX and Chen QX: Apoptosis induced by aqueous extracts of crocodile bile in human heptacarcinoma SMMC-7721. Appl Biochem Biotechnol 170: 15-24, 2013.

9. Song W, Shen DY, Kang JH, Li SS, Zhan HW, Shi Y, Xiong YX, Liang $\mathrm{G}$ and Chen QX: Apoptosis of human cholangiocarcinoma cells induced by ESC-3 from Crocodylus siamensis bile. World J Gastroenterol 18: 704-711, 2012.

10. Song W, Tian L, Li SS, Shen DY and Chen QX: The aberrant expression and localization of prohibitin during apoptosis of human cholangiocarcinoma Mz-ChA-1 cells. FEBS Lett 588: 422-428, 2014.

11. Qin F, Song Y, Li Z, Zhao L, Zhang Y and Geng L: S100A8/A9 induces apoptosis and inhibits metastasis of CasKi human cervical cancer cells. Pathol Oncol Res 16: 353-360, 2010.

12. Reed JC and Pellecchia M: Apoptosis-based therapies for hematologic malignancies. Blood 106: 408-418, 2005.

13. Hanahan D and Weinberg RA: Hallmarks of cancer: The next generation. Cell 144: 646-674, 2011. 
14. Stark GR and Taylor WR: Analyzing the G2/M checkpoint. Methods Mol Biol 280: 51-82, 2004.

15. Danial NN and Korsmeyer SJ: Cell death: Critical control points. Cell 116: 205-219, 2004.

16. Hunot S and Flavell RA: Apoptosis. Death of a monopoly? Science 292: 865-866, 2001.

17. Horowitz NS, Hua J, Powell MA, Gibb RK, Mutch DG and Herzog TJ: Novel cytotoxic agents from an unexpected source: Bile acids and ovarian tumor apoptosis. Gynecol Oncol 107: 344-349, 2007.

18. Yap TA, Carden CP and Kaye SB: Beyond chemotherapy: Targeted therapies in ovarian cancer. Nat Rev Cancer 9: 167-181, 2009.

19. Geurts van Kessel A: The cancer genome: From structure to function. Cell Oncol (Dordr) 37: 155-165, 2014.

20. Li Y, Wang K, Jiang Y-Z, Chang X-W, Dai C-F and Zheng J: 2,3,7,8-tetrachlorodibenzo-p-dioxin (TCDD) inhibits human ovarian cancer cell proliferation. Cell Oncol 37: 429-437, 2014.

21. Wang K, Li Y, Jiang YZ, Dai CF, Patankar MS, Song JS and Zheng J: An endogenous aryl hydrocarbon receptor ligand inhibits proliferation and migration of human ovarian cancer cells. Cancer Lett 340: 63-71, 2013.

22. Wang TT and Phang JM: Effects of estrogen on apoptotic pathways in human breast cancer cell line MCF-7. Cancer Res 55: 2487-2489, 1995

23. Earnshaw WC, Martins LM and Kaufmann SH: Mammalian caspases: Structure, activation, substrates, and functions during apoptosis. Annu Rev Biochem 68: 383-424, 1999.

24. Kang JH, Zhang WQ, Song W, Shen DY, Li SS, Tian L, Shi Y, Liang G, Xiong YX and Chen QX: Apoptosis mechanism of human cholangiocarcinoma cells induced by bile extract from crocodile. Appl Biochem Biotechnol 166: 942-951, 2012.

25. Espinoza I and Miele L: Notch inhibitors for cancer treatment. Pharmacol Ther 139: 95-110, 2013.

26. Pannuti A, Foreman K, Rizzo P, Osipo C, Golde T, Osborne B and Miele L: Targeting Notch to target cancer stem cells. Clin Cancer Res 16: 3141-3152, 2010.
27. Koch U and Radtke F: Notch and cancer: A double-edged sword. Cell Mol Life Sci 64: 2746-2762, 2007.

28. Nam Y, Sliz P, Pear WS, Aster JC and Blacklow SC: Cooperative assembly of higher-order Notch complexes functions as a switch to induce transcription. Proc Natl Acad Sci USA 104: 2103-2108, 2007.

29. Nam Y, Sliz P, Song L, Aster JC and Blacklow SC: Structural basis for cooperativity in recruitment of MAML coactivators to Notch transcription complexes. Cell 124: 973-983, 2006.

30. Borggrefe T and Oswald F: The Notch signaling pathway: Transcriptional regulation at Notch target genes. Cell Mol Life Sci 66: 1631-1646, 2009.

31. Yun J, Espinoza I, Pannuti A, Romero D, Martinez L, Caskey M, Stanculescu A, Bocchetta M, Rizzo P, Band V, et al: p53 modulates Notch signaling in MCF-7 breast cancer cells by associating with the Notch transcriptional complex via MAML1. J Cell Physiol 230: 3115-3127, 2015.

32. Jeays-Ward K, Hoyle C, Brennan J, Dandonneau M, Alldus G, Capel B and Swain A: Endothelial and steroidogenic cell migration are regulated by WNT4 in the developing mammalian gonad. Development 130: 3663-3670, 2003.

33. Yao HH, Matzuk MM, Jorgez CJ, Menke DB, Page DC, Swain A and Capel B: Follistatin operates downstream of Wnt4 in mammalian ovary organogenesis. Dev Dyn 230: 210-215, 2004.

34. Batheja N, Suriawinata A, Saxena R, Ionescu G, Schwartz M and Thung SN: Expression of p53 and PCNA in cholangiocarcinoma and primary sclerosing cholangitis. Mod Pathol 13: 1265-1268, 2000.

35. Ferrara N: Role of vascular endothelial growth factor in regulation of physiological angiogenesis. Am J Physiol Cell Physiol 280: C1358-C1366, 2001.

36. Redmer DA, Doraiswamy V, Bortnem BJ, Fisher K, JablonkaShariff A, Grazul-Bilska AT and Reynolds LP: Evidence for a role of capillary pericytes in vascular growth of the developing ovine corpus luteum. Biol Reprod 65: 879-889, 2001. 